\title{
The Social Warp of Science: Writing the History of \\ Genetic Engineering Policy
}

\section{Susan Wright University of Michigan}

\begin{abstract}
Traditional empiricism, although largely abandoned, has marked the social studies of science through the persistent division between macrolevel analysis of the institutions promoting and regulating science and microlevel analysis of the laboratory, theories, and experiments. Further traces appear in the largely separate methodologies used in social studies of science, which do not draw from political theory, and studies in political theory, which are silent with respect to the expression of power in the development of science. Poststructuralist conceptions of science have reinforced this division by encouraging a turn away from explanations that assume human agency and accountability. This article attempts to bridge the present methodological gulf between political theory and the social studies of science through methods that are sensitive to the nature and operation of power and to its expression in discourse. The application of these methods in the study of genetic engineering policy in the United States and the United Kingdom is outlined.
\end{abstract}

The broad contours of the genetic engineering story are well known: the first controlled genetic engineering experiments in 1972, which were uniformly recognized as a novel development, heralding the arrival of synthetic biology; the moratorium on research in 1974, as a result of which scientists voluntarily restricted their activities; the international conference at Asilomar, California, in 1976; the intense public controversy that captured

\footnotetext{
AUTHOR'S NOTE: For details of the analysis presented in outline in this article and complete references to primary sources, readers are referred to the full-length study, Molecular Politics: The Formation of Regulatory Policy for Genetic Engineering in the United States and Britain (forthcoming, University of Chicago Press), on which the article draws. Special thanks to Carola Carlier, Richard Falk, Tom Gieryn, Paul Grams, Donna Haraway, Everett Mendelsohn, and Charles Weiner for stimulating responses to drafts and encouragement during the evolution of the position developed here. Research was supported by a Rockefeller Humanities Fellowship and National Science Foundation grants SES7826618 and SES8511131.
} 
the attention of Congress as well as several local communities in 1977; and finally, the disappearance of the issue and the rapid deregulation of the field in the early 1980 s.

The received interpretation of these events is also well known. The locus classicus is the retrospective account by Donald Fredrickson, the National Institutes of Health (NIH) director under whom the controls were first developed and later dismantled, presented at the annual meeting of the American Association for the Advancement of Science in 1982. ${ }^{1}$ The title of Fredrickson's talk was "Science and the Cultural Warp" - an accurate indication of two of the main parameters he used in his history, namely, "science and its practitioners," on the one hand, and "the public," assumed to be immersed in a prevailing "anti-scientific" culture on the other. In this account, the dismantling of the American controls is portrayed as rationally directed by technical experts with privileged access to specialized knowledge in the face of resistance from an irrational public. The genetic engineering episode is cast as a war between truth and error, rational analysis, and irrational alarmism, in which rationality and truth ultimately won.

In this article, I offer a competing interpretation of the evolution of American recombinant DNA policy. However, with a broad debate about "the objectivity question in history" in progress, such an attempt requires some preliminary justification. ${ }^{2}$ In what sense, and according to what criteria, can a historical account claim to interpret and explain its subject matter? I address this question in the section that follows, then turn to the genetic engincering case itself.

\section{The Challenges of Empiricism and Poststructuralism}

The history and sociology of science, liberated in the 1960 s from traditional empiricism, embarked on important studies showing that science is as much a product of its social environment as an account of natural phenomena; a variety of sociological schemata to conceptualize the "social construction" or "shaping" of science and technology have also resulted. The fading of empiricism also opened the study of scientific development to the influences of feminism, poststructuralism, and hermeneutics. Although differing in important respects, all of these intellectual currents broke with the Rankean ideal of history as a politically neutral, objective account of the past.

This new emphasis has produced investigations and analyses of the laboratory as the site of construction of scientific knowledge, of experiments and experimental practice, of scientific discourse, and of the mobilization of discursive and visual resources in the pursuit and promotion of science. ${ }^{3}$ But, 
whether they focus on behavioral minutiae of laboratory life, on the wispy interface between the material world and the discourses purporting to describe it, or on novel conceptual schema with which to analyze science, many current studies are marked by a kind of epistemological agnosticism: The insistence of laboratory ethnographers on intractable particularity leaves little room for generalized understanding beyond the heightened self-awareness of the observer, their protests to the contrary. And some have embraced extreme forms of relativism, claiming that to attempt to understand social or natural worlds is to construct mirages. According to that view, the objects that we would claim to encounter cannot survive that claim on them; they dissolve into the verbal images constructed of them.

On the other hand, much is still being written about science that embraces empiricist conceptions of its history; the assumption that science and its methods are isolated from social influence is still deeply embedded in the natural sciences and the general culture. Science purportedly achieves truth, climinates error, and disseminates objective understanding; and its history merely recounts that process. The received view of the history of genetic engineering policy is a case in point.

Considerable evidence concerning the evolution of genetic engineering policy throws such views into question, however. First, the sociopolitical context of policy making cannot be ignored. It is notable that nowhere in Fredrickson's account is there mention of the relevance of the social, political, and economic contexts in which recombinant DNA policy evolved, and of the growing interests in industry and government circles in developing the new field rapidly. That the early years of the 1970 s when the possibility of genetic engineering was demonstrated were also a time when scientists were coming under increasing pressure to demonstrate the utility of their research and when private industry was turning to new fields of high technology as sources of high returns on investment, that in the period 1979-82 the infant genetic engineering firms were competing fiercely for products and patents, as were multinational chemical and pharmaceutical corporations for "windows" on this field, and that nation-states, individual states within the United States, and universities were all struggling for a piece of the action - none of this figures in Fredrickson's story. Nor is there mention of the powerful interests emerging in the late 1970s to promote deregulation of industry. Yet there is abundant evidence that these trends were highly influential in shaping interests in the emerging field of genetic engineering as well as perceptions of its social uses and impacts. The received view does not attempt to explain why such evidence can be set aside.

To assume that the formation of genetic engineering policy was a dispassionate, politically neutral process of technical assessment excludes any 
analysis of its sociopolitical context. A portrait of scientists, government representatives, and corporate executives objectively assessing the implications of recombinant DNA technology on purely technical grounds can be nothing more than a silhouctte. Moreover, the received view takes the discourse about the issues posed by genetic engineering as self-evident: It cannot explain why the terms and categories of debate changed over time or why those in Britain and the United States differed significantly.

There are thus two main temptations involved in writing the history of genetic engineering policy: on the one hand, the empiricist impulse to exclude social influences entirely, offering the writer the satisfaction of producing an account not rendered ambiguous or problematic by consideration of the (by no means clear and unambiguous) society in which policy was made; on the other hand, the poststructuralist impulse to insist that both science and history are shot through with social and cultural influences but to deny the possibility of a privileged view of either.

\section{Bringing Power Back In}

To avoid the reductionism characteristic of each polarity, I assume neither that the history of genetic engineering policy reduces to a narrative of technical decisions reached in the course of a rational process of technical assessment nor that discourse analysis or "thick description" alone is adequate to an explanation of events. The crucial element that each approach excludes by its own theoretical premises is an investigation of the political economy of science - the power relations affecting the direction and pace of research and development that crystallize in government policy. The received view, in claiming that policy rests on a technical logic, would deny that power relations are relevant; the broad tendency of poststructuralist treatments of science is to ignore them. ${ }^{4}$

Yet genetic engineering - from its inception an obviously major scientific and technological resource - provoked in those responsible for its development and control actions and arguments that demand political and economic analysis. Examining this dimension of genetic engineering policy is crucial to explaining its development. The history of policy formation needs to be investigated in ways that are sensitive not only to technical and cultural characteristics of the issues raised by genetic engineering but also to the nature and operation of the power relations characterizing its actors.

Thus in the background of the choice of a theoretical framework are several issues concerning the nature, operation, and location of power, assumed in its most general form to be a capacity attributed either to human agents or to systcms in which they act, to bring about effects on other actors 
(who, it is assumed, would act differently in its absence). ${ }^{5}$ First, there is the question of who exercises power and how? Is power possessed by agents (either individuals or social groups) or is it an attribute of systems or structures? A voluntarist tradition that runs from Hobbes and Locke to Wright Mills, Dahl, and Lukes assumes that the historical subject has an "ineradicable and perhaps crucial explanatory role," rooted in the complementary ideas of human agency and human responsibility; in contrast, various forms of structuralism posit systemic relations as fundamental and, in the limiting case, as determining human action. Debates in the 1950s between C. Wright Mills and Talcott Parsons and in the 1970s betwcen Marxists Ralph Miliband and Nicos Poulantzas exemplify these polarities. ${ }^{7}$

Because various social groups were visibly struggling over genetic engineering policy, it seems reasonable to assume both that these actors were (voluntarily) pursuing their interests and also that they did so within limits set by possible structural constraints. It also seems important to leave open the possibility that agents may act to change and modify structural constraints. Consequently, this study examines the evolving social, economic, and political contexts in which genetic engineering developed and how interests in the field were formed and constrained in these contexts. The problem of identifying and locating "interests" seems relatively uncontroversial in practice, although it has attracted considerable theoretical debate. ${ }^{8}$ Interests often insist on being heard, and when they do not, they are often expressed in other types of activity that are equally noteworthy.

Second, there is the epistemological question of how power is properly to be located - an issue that gave rise to an extended debate in the 1960s and 1970 s, mainly in the American political science community. Members of the "pluralist" school assumed not only that power is distributed throughout democratic societies but also that its operation should be determined by investigating observable behavior, specifically, the decisions taken in formal policy arenas. ${ }^{9}$ This position was countered by "postpluralists" Schattschneider, Bachrach, and Baratz, who argued generally that power in democratic socicties was far more concentrated, operating most crucially and influentially out of sight of those who can see only the formal policy process. ${ }^{10}$ In Schattschneider's words: "The flaw in the pluralist heaven is that the heavenly chorus sings with a strong upper-class accent. Probably about 90 percent of the people cannot get into the pressure system." "11 Postpluralists therefore argued that it was not sufficient to confine attention to concrete decisions made in the formal policy process, because that approach excludes any consideration of the informal processes taking place elsewhere that might affect the scope of the issues placed on the formal agenda. These might ultimately be more influential for policy formation than formal decisions. 


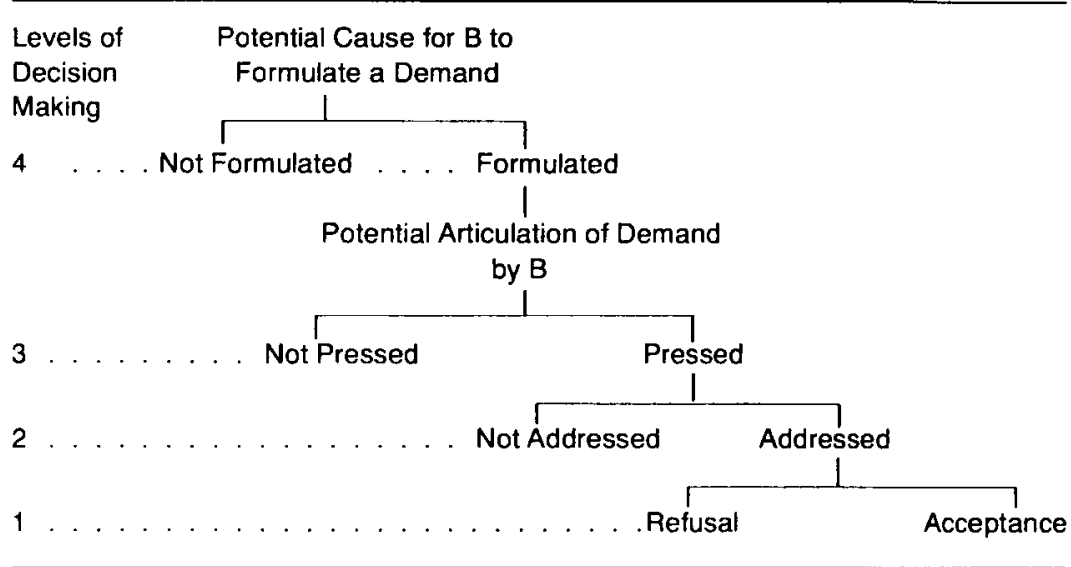

Figure 1

SOURCE: Adapted from Saunders $(1979,29)$.

The nature of the debate between pluralists and postpluralists is nicely represented by Saunders in a diagram (see Figure 1). If B wishes A to address a demand, the matter may be taken up in a formal policy arena and either accepted or rejected (level 1). Or A may take steps to ensure that the matter is kept off the formal agenda through a variety of tactics (level 2). Or B may fail to articulate the demand because he or she anticipates that it will be rejected or ignored (level 3). Finally, B may even fail to formulate his or her demand because $A$ is able to influence or even determine B's very desires (level 4). As Schattschneider memorably registered the nonneutrality of organizations at all of these levels: "All forms of political organization have a bias in favor of the exploitation of some kinds of conflict and the suppression of others, because organization is the mobilization of bias. Some issues are organized into politics while others are organized out." ${ }^{12}$

Although pluralists held that only events at level 1 could be observed, postpluralists Bachrach and Baratz argued that what they called "nondecisions" at levels 2, 3, and 4 were equally, if not more, important: "Of course power is exercised when A participates in the making of decisions that affect B [level 1]. But power is also exercised when A devotes his energies to creating or reinforcing social and political values and institutional practices that limit the scope of the political process to public consideration of only those issues that are comparatively innocuous to A [levels 2-4]." ${ }^{13}$ In other words, interests act and power is exercised not only in votes "on stage" but also in determining such matters as the selection of a policy arena, the 
appointment of decision makers, the organization of agendas, and the dissemination of decisions. Such actions, they claimed, might never be registered formally but could mark the outcome significantly. Thus they represented a "second face" of power that had been ignored by pluralists.

Pluralists responded by arguing positivistically that, because only decisions in a formal arena were observable, the second face of power did not exist. ${ }^{14}$ Bachrach and Baratz defended their position by claiming that nondecisions could be observed whenever there was conflict, because this would allow covert as well as overt grievances to surface. ${ }^{15}$ For Lukes, such a defense conceded far too much epistemological ground. To assume that conflict was necessary to register the operation of power neglected its "most effective and insidious use," namely, to prevent conflict from ever arising. According to Lukes, "to assume that the absence of grievance equals genuine consensus is simply to rule out the possibility of false or manipulated consensus by definitional fiat." The most fundamental operation of power was to manipulate "perceptions, cognitions and preferences" in such a way that pcople failed even to formulate demands. ${ }^{16}$

Precisely how interests could be defined in the absence of conflict remained a question over which many took issue. Some, notably Habermas, adopted a realist's position, claiming that "real" interests can be defined theoretically through a (hypothetical) process that produces consensus through "free, undistorted, and unrestricted argument." ${ }^{17}$ Lukes, in contrast, adopted a constructivist position, maintaining in response to a critic that the analysis should be at once "value-laden, theoretical and empirical." 18 How this approach to interests might be elaborated, however, remained unclear.

This article adopts a framework that is both postpluralist and constructivist in orientation. It is assumed, first, that policy arenas generally bear the imprint of their creators in the form of structural bias that unevenly distributes influence, access, and control of the agenda and that the effects of bias should be investigated at all levels of policy formation identified above. Beyond a postpluralist analysis of the operation of interests, the study also emphasizes the importance of examining their historical formation. Rather than posit "real interests" as Habermas (1970) does, I assume that interests are contingent, shaped by historical circumstances, and that the processes by which values, belicfs, and practices become characteristic of a community and its interests should be investigated. This approach can be used to elucidate the most problematic level of "non-decision making" (level 4) identified by postpluralists - the shaping of values and preferences so that some issues are not even formulated. Lukes notes that "bias...is not sustained simply by a series of individually chosen acts, but also, most importantly, by the socially 
structured and culturally patterned behaviour of groups, and practices of institutions." ${ }^{19}$ How such behaviors and practices are related to the formation of interests should be an important focus of historical inquiry.

\section{Power and Language}

A third issue concerning power - the relation between power and language - has been raised by poststructuralists, notably Foucault. Foucault placed "discursive practice" at the center of his analysis of social systems, arguing that such practices embody power by supporting a "normalizing gaze" - a socially defined system of rules that permits certain statements to be made, orders these statements, allows us to identify some statements as true, others as false, and still others as irrelevant. ${ }^{20} \mathrm{His}$ achievement was to demonstrate the organic, systemic relations between discursive practices, disciplinary techniques, and social institutions, challenging in the process the liberal separation of truth and power. As he expressed this challenge: "Truth isn't outside power or lacking in power: . . truth isn't the reward of free spirits, the child of protracted solitude, nor the privilege of those who have succeeded in liberating themselves. Truth is a thing of this world: It is produced only by virtue of multiple forms of constraint." ${ }^{21}$ Consequently, " 'truth' is linked in a circular relation with systems of power which produce and sustain it, and to effects of power which it induces and which extend it." 22

By claiming that power achieves its effects through disciplinary practice, Foucault refocused the problem of power from the voluntarist concern with "regulated and legitimate forms of power in their central locations" to their "ultimate destinations with those points where it becomes capillary [completely dispersed]." ${ }^{23}$ In contrast to a voluntarist conception that associates power with actors or agents, Foucault argued that the analysis of power should not "concern itself with . . . conscious intention or decision" and that it should refrain from attempting to locate power. Instead, the analysis should work at the level of "on-going subjugation, at the level of those continuous and uninterrupted processes which subject our bodies, govern our gestures, dictatc our behaviors, etc." 24

Within the sociology of science, a move rather parallel to that of Foucault was made by Callon, Latour, and others in transferring the focus of analysis from the interests of scientists and of other agents to "networks" or "actorworlds" - alliances of human and nonhuman elements, such as scientific and technical institutions, scientists, and the objects and procedures that scientists create. The development of science and technology is conceived as the process of formation of such networks and, in particular, the formation of relatively stable ensembles of procedures, instruments, theories, results, and 
products to which various actors give their allegiance. Like Foucault's approach to discursive practice, this approach dissolves voluntarist conceptions of interests into merely the "temporarily stabilized outcomes of previous processes of enrollment." 25

The poststructuralist move to place disembodied discursive practices (Foucault) or networks (Callon and Latour) at the center of analysis has occasioned vigorous criticism from those who wish to preserve clarity both on normative issues concerning the use of power as well as on explanation of development and change. Nancy Hartsock argues that Foucault's exclusive emphasis on the capillary nature of power - the sense that power is dispersed through networks and hence is everywhere - makes any concept of accountable exercise of power disappear. Hartsock argues further that in replacing the traditional idea of sovereign power with the conception of power as existing in local material institutions, methods that analyze the effects of power exerted by large institutions are also replaced by methods that focus exclusively on local, individual levels: "Power [for Foucault] is everywhere and so ultimately nowhere." Thus Foucault ultimately produces a disorienting sense of ungroundedness: In rejecting attempts to define the sources of power or reasons for transformations of discursive practice, he finally "stands on no ground at all." 26

Steven Shapin has pursued a roughly parallel line of argument with respect to Latour's dismissal of interests and rejection of explanation as a goal in accounts of the development of science. Shapin notes that, although Latour appears to ban interests, they are assumed in the background of his account because his view of science is firmly rooted in his assumption that technoscience is goal directed. But why science should be goal oriented, and who is generating and defining these goals is not addressed. Shapin, like Hartsock, is uneasy with the ungroundedness of Latour's position: "This is a world in which anything and anybody can be an actant or an actor.... It is the world of the seamless web, a world in which everything is connected to everything else... Ultimately, those that truly inhabit the seamless web can say nothing intelligible about its nature, even, if they are consistent, that it is seamless and that it is a web." 27

An important purpose of my study of genetic engineering policy is to show how the discursive character of policy making is related to structural bias. Discourse, understood in a Foucauldian sense, is treated (in a nonFoucauldian, causal manner) as linked not only to preferred practice but also to the power to control the policy arena. The analysis below draws attention to the effects of the choice of discourse and the close relation between discourse and practice at all levels of policy making (Figure 1), but, in contrast to a poststructuralist analysis, it does so in relation to the evolution 
of interests in shaping the policy arena. The process of establishing a specific discourse may be expected to reveal much about the politics of a given policy arena because discourses achieve currency for political reasons.

One further methodological point is important. In this study, comparative analysis of policy formation in two countries that developed distinct systems of government control for genetic engineering is used for two main reasons: first, because differences in either conception or implementation underscore the arbitrary nature of decisions that might otherwise be seen as "natural" or "logical"; second, because interactions between two national systems provide important indications of the operation of transnational influences (especially, in this case, the influence of corporations and international scientific organizations and the interests of national governments in supporting the ability of their scientists and corporations to compete internationally).

\section{Underdetermined But Not Unconstrained}

To return to the question raised initially about the possibility of historical interpretation and explanation: This treatment of the development of genetic enginecring policy is located neither in the traditional empiricist camp of those who see history as simply "uncovering" the past nor in the various poststructuralist camps of those who insist that texts are all we can know. History reduces neither to the sum of the facts nor to the sum of the texts. Analyzing in terms of sociopolitical context, decision and nondecision making, and discourse can produce an account of the history of genetic engineering policy that not only reinterprets the limited data used to support the received explanation exemplified by Fredrickson's 1982 lecture but also goes much further, providing a view of the political and economic interests that shaped genetic engineering policy.

The position taken here is that the objects of history, although they may be underdetermined, are never unconstrained. They will be accommodated to the political values and commitments of their examiners, the methods of inquiry adopted, and the cumulative impact of evidence on which inquiry draws. As such, historical interpretation enters a larger process of debate and dialogue in which its claims and the relations, categories, and values it uses in establishing them are tested against competing positions. As Joan Scott observes, "Written history both reflects and creates relations of power. Its standards of inclusion and exclusion, measures of importance, and rules of evaluation are not objective criteria but politically produced conventions.... There are contests, more or less conflictual, more or less explicit, about the substance, uses, and meanings of the knowledge we call history." 28 


\section{The Development of American and British Recombinant DNA Policy}

The remainder of this article outlines how the methods described above can be applied and how they produce an interpretation of the formation of genetic engineering policy that not only competes with the received view but encompasses a much wider range of evidence. Two phases of this history will be addressed: first, the formation of genetic engineering policy in the United States and the United Kingdom in the period 1972-75 and, second, the dismantling of controls in both countries in 1978-82.

\section{The Formation of Genetic Engineering Policy, 1972-76}

The initial response to the advent of genetic engineering came from the community of biomedical researchers close to the emerging field. A largely internal debate about possible hazards led scientific leaders and institutions with which they were connected to form committees in 1974 to address the risk issue (the Berg committec under the auspices of the National Academy of Sciences [NAS] in the United States and the Ashby committee, appointed by the Advisory Board to the Research Councils in Britain); to organize an international conference at Asilomar, California (1975); and to promulgate government controls aimed at containing laboratory hazards. The standard view of this response portrays these developments as a rational progression, from initial inquiry to a technical response based on expert opinion. However, as emphasized earlier, the actual concrete decisions that constitute policy development are understood accurately only by examining how social interests shaped perceptions and governed the formal and informal processes that defined the institutional environment, restricted participation in the decision process, and limited the scope of the issues addressed.

The advent of genetic engineering activated diverse and often conflicting interests in its future development: The scientific community, universities, exccutive branches of governments, private industry, labor unions, and pressure groups all responded in ways shaped by their own specific goals. ${ }^{29}$ The interests of scientists and their universities were affected by changes in the emphasis of government sponsorship of science that began in the mid1960s. In the United States, the leveling-off of the postwar exponential growth in government support and calls for accountability from politicians brought to the fore the utilitarian dimension that had always been present in the American research effort. Practical results from science assumed increasing importance in the eyes of politicians and the bureaucrats who oversaw 
the American research effort. Similar pressures developed in Britain. There, too, a decline in government support for civilian science set in, particularly after 1973, when both sides of the British dual support system - the universities and the research councils - were hurt by cuts in government funding. Commitment to protecting the autonomy of the universities and scientific research (previously a stronger tradition in Britain than in the United States) gave way before a growing emphasis on accountability and practical results. The prospect that genetic engineering would produce not only important progress in solving fundamental biological problems but also a wide array of practical applications fitted well with this new policy emphasis on both sides of the Atlantic.

Consequently, the new field promised to fulfill several needs. For scientists, the techniques promised not only the novel directions in research and the fast results required by serial-competitive funding arrangements but also a powerful justification for continued support. Because molecular biology had yielded spectacular theoretical advances but almost nothing in terms of practical results, the prospect that genetic engineering would lead to the latter made it especially valuable to researchers. For university administrators, the techniques offered a prospect of generous and diverse sources of funding in a period when support had become less assured, and when the ability to demonstrate a practical payoff was becoming a significant criterion in assessing grant applications. For the government agencies responsible for promoting biomedical research (the U.S. NIH and the U.K. Medical Research Council), genetic engineering offered both scientific advances of the type that would foster national preeminence in science and practical applications that would demonstrate the utility of the biomedical sciences to politicians. These prospects were immediately perceived and defined in terms of international competition. Both in the United States and in Britain, it was feared that significant delays in development might hamper researchers in what was seen as a race with other countries.

The private sector had additional reasons for interest in genetic engineering: The techniques signified potential sources of new products and, just as important, a new, energy-efficient mode of production. This meant at once a threat to existing sources of profit and new opportunities for obtaining a high rate of return on investment. Although large multinational pharmaceutical, chemical, and energy corporations did not immediately take action, they established ways to monitor closely the development of the field.

For each of these groups, the continuing development of recombinant DNA technology held a powerful attraction; few among them were likely to bear delaying the work patiently. 
While competitive interests in the new biology were being activated in academia and industry, both the effects and the direction of Western science and technology were being challenged more vigorously than ever before. These challenges to unrestrained deployment of science and technology took different forms in the United States and Britain but were influential in both countries. In the United States, a diverse public interest movement had mobilized to secure legislation aimed at two main goals: prevention of the undesirable side effects of technology and expansion of public participation in regulatory policy. The liberal Congresses of the late 1960 s and early $1970 \mathrm{~s}$ responded by enacting a mass of environmental and safety legislation. The regulatory impulse of the late 1960 s and early 1970 s opened policy processes within government agencies to public scrutiny, but it is important to register that control over those processes remained the prerogative of government and industry: "Public participation" was largely limited to access to information and the right to air positions at public hearings. The environmental movement was given a voice but not a formal policy arena.

In Britain, reforms were more muted and in general did not significantly change a tradition in which regulatory controls were a matter of negotiation between private industry and government officials and largely shielded from public scrutiny. But one important exception to that generalization was the Health and Safety at Work Act enacted in 1974, which gave employees extensive rights to representation both locally and on the tripartite Health and Safety Commission. Trade unions, whose numbers grew substantially in the 1960 s and 1970s, had not only a voice but also a formal arena. Furthermore, technicians and many scientists in research laboratories were unionized. In contrast to the situation in the United States, where few laboratory workers belonged to unions, British trade unions constituted a significant countervailing force with a strong influence within the Labour government.

These various interests were activated in the years following the appearance of genetic engineering techniques in the early $1970 \mathrm{~s}^{30}$ Initially, the techniques triggered a mainly private debate within the community of scientists close to the emerging field. Considerable concern was aired about possible environmental and social impacts of the technology. As Cambridge University molecular biologist Sydney Brenner wrote to the Ashby committee in 1974, "The essence is that we now have the tools to speed up biological change and if this is carried out on a large enough scale then we can say that if anything can happen it certainly will." Brenner went on to warn of the problems of controlling defense laboratories and drug companies "that can and often do practice secrecy in their activities." ${ }^{31}$ At the other end of the spectrum, others focused on the possibility of moves to control biological 
research. Joshua Lederberg, then at Stanford University, wrote to a colleague, "There is really a great danger of the whole matter getting seriously out of hand and encumbering important research." 32

At this stage, there was no single discourse, no single definition of the problem, but within a year, that situation changed, as the biomedical research community moved early on to transfer responsibility for an initial assessment of the issue to the NAS (in the United States) and to the Advisory Board for the Research Councils (in the United Kingdom). The obvious differences between the British and American institutions responsible for forming an initial policy assessment in Britain and the United States - the one public and the other semiprivate - should not obscure their functional similarities: Both were oriented toward promoting biomedical research, and their primary constituencies were the communities of British and American biomedical researchers. Members of the committees and groups appointed by these institutions - the Ashby committee in Britain, the Berg committee in the United States, and the Organizing Committee for the Asilomar Conferencewere drawn almost exclusively from their constituencies.

With the establishment of policy arenas in place - that is, with the structural bias of British and American policy arenas settled -other decisions seemed natural. In particular, the scope of the genetic engineering issue was radically reduced and redefined as one of "containing" unknown biohazards. The question of social use of genetic engineering was consistently bracketed. ${ }^{33}$ As molecular biologist Paul Berg (a pioneer in the techniques, chair of the NAS committee, and cochair of the Asilomar conference) held in 1974, the issues raised by genetic engineering were not moral or ethical but matters of public health. ${ }^{34}$ The genetic engineering "problem" was thus framed in terms of finding a technical response to a technical problem. This reduced, technical discourse was almost unanimously embraced (within the biomedical research community). On both sides of the Atlantic, those who contributed to the policy process would work largely within the boundaries of this discourse.

Thus discourse and policy developed in a synergistic interaction with one another. The procecdings of the Asilomar conference, for example, show that a reductionist discourse bearing within it the seeds of a technical solution was both an expression of scientific and economic interests in developing the field without external intervention and at the same time a powerful contributor to defining and reinforcing the central role of the biomedical research community in policy making. It was in the interests of nearly all admitted to policy-making arenas that they not jeopardize control of policy by dissension, apparent inaction, or admitting as central those dimensions of the issue that obviously transcended the expertise of scientists. 
In the United States, voluntary controls for genetic engineering research were developed by an expert panel convened under the auspices of the NIH and promulgated in 1976. In Britain, policy making initially followed a similar course. The Ashby committee proposed that work could be resumed under a voluntary code of practice using suitable technical controls. This approach was in harmony with the kinds of controls anticipated by the Berg committee - which was no coincidence because Berg, Ashby, and others were in close contact with one another. A second committee - the Williams committee - worked out a framework for categorizing hazards that bore a distinct resemblance to that developed by the NIH. The strong anticipation of the British scientific community in 1975 was that genetic engineering would become the responsibility of a small expert committee - "a kind of peer group," as one scientist later recalled. ${ }^{35}$

In fact, those expectations were not realized in Britain. In the mid-1970s, with a Labour government in office, the scientific and technical unions were able to exert influence, first, in defining the genetic engineering issue as an occupational health and safety problem; second, in pressing for regulation; and, third, in insisting on representation in the policy arena.

What emerged in Britain, in contrast to the United States, was a kind of compromise between the interests of the research establishment and those of the unions: The Health and Safety Commission (HSC, roughly equivalent to the Occupational Safety and Health Administration [OSHA]) would regulate; the Medical Research Council would provide the secretariat - in other words, would control the flow of advice to the HSC. And ambiguously positioned between the two institutions was an anomalous creature known as "GMAG" - the Genetic Manipulation Advisory Group - formally existing outside both agencies as a QUANGO (quasi-autonomous nongovernmental organization). A broadly constituted committee with representation of the scientific, business, and labor sectors as well as of the vaguely defined public, GMAG was sometimes referred to as an "experiment in social democracy," brainchild of the secretary of state for education and science, Shirley Williams. But it was more (or less) than that, for it was expected by the government bureaucracies that created it to function within the frameworks developed by the Ashby and Williams committees. Thus what GMAG would accomplish was more than simply the outcome of balancing conflicting interests: Resolution of conflict on GMAG took place largely within a preexisting framework of assumptions and practices.

Despite that qualification, British and American policies took different turns at this point as a result of the countervailing influence of the trade unions. In particular, the two national discourses on the genetic engineering problem diverged: in Britain, biohazard meant primarily hazards to employ- 
ees in laboratories and industry and secondarily hazards to the public. In the United States, the term acquired the reverse sense.

\section{Deregulation, $1979-82$}

For several years, from roughly 1977 to 1979 , the British and American systems diverged. The voluntary NIH controls survived a storm of public criticism as well as congressional efforts to pass regulatory legislation. As congressional interest faded away in 1978, the NIH and its RAC focused on relaxing these controls. Meanwhile, the British GMAG, together with the HSC, proceeded to implement a code of practice based on the initial appraisal of hazards in 1976 and formulated within the regulatory framework defined by the Health and Safety at Work Act. By the beginning of 1979, the British perceived themselves to be "wildly out of line" with the United States. However, by 1982 , the substantive and procedural requirements of the two systems again resembled one another: By that point, both systems required minimal controls for most experiments and industrial processes.

An obvious question is why the distinct differences between these two systems of controls, produced initially because of the influences of different interest groups, eventually disappeared. The received view attributes this convergence to a technical resolution of the biohazard controversy. However, examination of the data that members of the RAC and the GMAG were asked to consider reveals enormous uncertainties about hazards and very little empirical data about which there was any solid consensus. For example, the early focus on the hazards of using the bacterium $E$. coli $\mathrm{K} 12$ as a cloning host became merely academic as the range of such vehicles expanded. ${ }^{36}$ Nor is a poststructuralist analysis helpful: A focus on discourse alone cannot explain the changes of discourse that took place. In contrast, the position taken here is that an explanation must be sought both in the changes in the social and political contexts of decision making that occurred in the late 1970 s and early 1980s and in the ways these changes affected the interests being expressed within official and unofficial policy-making bodies.

\section{Evolution of American Policy, 1977-82 37}

In the United States, two main changes, one political, the other economic, shaped interests in the rapid development of genetic engineering and opened the way for pursuing that goal. In the first place, the biomedical research sector (with the quiet support of industry) rallied to organize an extensive effort to derail the genetic engineering legislation. The success of this effort established the ability of the biomedical research sector and industry to 
control the policy arena. This success was notably in part a result of and also a reinforcement for changes in biohazard discourse, namely, that "new evidence" showed that the biohazards had been exaggerated. ${ }^{38}$

In the second place, there were clear signs by 1978 that the techniques promised profitable commercial application. Investment in genetic engineering in the United States from corporate and venture capital sources began to increase exponentially and continued doing so until the early 1980s. NIH support also increased rapidly, more than doubling between 1978 and 1980. In addition, an extended campaign on the part of the private sector for government support for technological development began to bear fruit in the form of the patent, budget allocation, and tax policies of first the Carter and later the Reagan administrations. These policies encouraged joint universityresearch programs in biotechnology, provided tax incentives for private investment in research, and permitted universities to patent the results of research funded by the federal government. These policies had the effect of pumping millions of dollars of corporate and venture capital into the field thus further heating what was already a hot competition. ${ }^{39}$

A transformed recombinant DNA field saw both its sponsors and its practitioners assume new social roles. As developers of patents on basic techniques, as recipients of corporate grants for research, and as cosponsors of new biotechnology companies, leading research universities established major interests in the industrial development of the field. And so also did research scientists, as equity holders, advisers, consultants, and executives for new genetic engineering companies and multinational corporations. As competition accelerated, pressures to pursue rapid development intensified and multiplied. In the late 1970 s and early 1980 s, corporate representatives and scientists alike framed the genetic engineering problem in terms of a "race" in which the NIH controls presented a major "handicap."

Private industry, which until that point had kept a low profile, began to press actively for weakened controls, although not as visibly as the biomedical research sector. Privately, corporations pressured the NIH to adapt the NIH guidelines to their requirements. The features they particularly criticized were the time-consuming procedures that required review by the large Recombinant DNA Advisory Committee (RAC) and what they considered to be too stringent safety requirements. In fall 1978, representatives of the Pharmaceutical Manufacturers Association told the NIH director that govemmental limitation on the size of permissible cultures of genetically manipulated organisms was "a timely issue." ${ }^{40}$ Less decorously, Genentech (one of the leaders of the new genetic engineering firms that appeared in the 1970s and 1980s) began to play hardball. The firm, which had negotiated a major contract with Lilly for insulin production and was in the process of construct- 
ing a fermenter for large-scale cultures, threatened to ignore the NIH controls unless these were reduced, on the ground that NIH review risked revealing proprietary data and also on the ground that the risks were minor. ${ }^{41}$ Because the NIH took no public action to respond to such arm-twisting, companies like Genentech could press their agendas with impunity.

The Genentech affair also pinpoints the difficult double standard in NIH relations with industry and academia. NIH had no legal authority to require companies to comply with its guidelines - Genentech was flaunting only a moral requirement, not a legal one - whereas scientists funded by the NIH had no such license. Although their counterparts in industry could move quickly with experiments, NIH grantees were often delayed by requirements for review. And they had to divulge full details of their research-again a discriminatory requirement in this increasingly competitive field. In 1978, scientists were rumored to be voting with their feet - taking their projects to countries with weaker controls. This again pressured the NIH to relax controls.

At the same time, countervailing pressures for caution were enormously weakened both by the demise of regulatory legislation and by the successes of a corporate campaign for general deregulation, which the Carter administration to an extent and the Reagan administration entirely endorsed. When it became clear, toward the end of 1978 , that Congress was unlikely to act to control genetic engineering, public advocacy groups had almost no leverage in the policy arena.

The strong (and, on this point, convergent) interests of the biomedical research community and industry in weakening the NIH controls were expressed initially in terms of the reshaping of the structural bias of the principal policy arena, the NIH RAC, with important and subtle adjustments in the committee's composition and agenda. One expression of these changes was a distinct shift in the discursive character of policy making. Previously, NIH policy had stressed anticipating and forestalling unknown biohazards so that the burden of proof fell on practitioners of genetic engineering to demonstrate the safety of their techniques. ${ }^{42}$ After establishing the ability to turn back congressional interest in regulation, that power could then be deployed further to reconstitute the biohazard discourse.

In spring 1978, the NIH director announced to his advisory committee that it was time for the burden of proof to shift to the public, to show that genetic engineering was hazardous; the techniques henceforth would be innocent until proven guilty. In the following years, the discourse and practice of "containment of unknown biohazards" gave way to the claim that genetic engineering posed "no extraordinary hazard" and therefore no longer 
required special precautions. In Foucauldian terms, a new system of power was sustaining a new discourse.

The NIH controls were revised significantly in December 1978 and more radically in January 1980, when the NIH director approved a proposal to drop special containment requirements for most procedures that used the bacterium $E$. coli $\mathrm{K} 12$ for cloning. A policy of crisis intervention replaced the previous policy of hazard prevention. The decision was a clear victory for the biomedical research and private sectors pressing for deregulation, and, in the absence of any significant constituency opposing deregulation, the subsequent dismantling of virtually all controls for laboratory research and industrial production using genetic engineering was predictable.

\section{The British Response, $1979-82^{43}$}

The British were surprised by the precipitous turn toward deregulation in the United States. One GMAG member recalled the atmosphere early in 1979: "There was an element of panic here. ... People will put up with being marginally out of line but not [to that extent].... We were in real trouble." Growing professional and commercial interests in developing the technology in Britain (as in Europe generally) began to press for looser controls. "This was one time when scientists were threatening to leave and meant it," the GMAG member recalled. ${ }^{44}$ Industrialists warned in parliamentary hearings that Britain was about to lose "a vital new heartland technology." "Missing out on a revolution in biotechnology" and "losing a generation of the best young scientists [in molecular biology]" became rallying cries for those who opposed the British controls. Further pressure on the British government was exerted by the influential European Molecular Biology Organization, which endorsed the more lenient American controls issued in December 1978.

In 1979, the Labour government responded to rising industrial interests in genetic engineering by appointing a high-level committee composed of members with strong interests in the industrial application of genetic engineering. Representatives of the general public and the trade unions were conspicuously excluded. The committee produced a "hard-hitting and interventionist" report, calling for strong government promotion of biotechnology, including support for a national biotechnology company, and waming of the "possible prejudicial consequences to British industry" if British controls exceeded those elsewhere.

At the same time, the unions' commitment to caution was losing ground on GMAG. The new chair of the committee, Sir William Henderson, appointed at the beginning of 1979 , made it clear from the start that the committee's responsibility for considering biohazards would not inhibit the 
realization of potential benefits. (Presumably, Henderson was confident of the government's support.) With the election of Margaret Thatcher in May 1979 , the unions lost any remaining influence they had with the government. Thatcher attacked the unions in many ways, undermined their public support, and cut funding for government agencies, such as the HSC, that provided their principal policy arena.

This changed political climate played a great part in GMAG's subsequent weakening of its earlier controls. By the beginning of 1978, GMAG was using a risk assessment scheme developed by Brenner and others. The details of GMAG's application of this scheme are interesting because they demonstrate the way in which technical variables were shaped by the political context: Each time the American controls were reduced, these variables were appropriately adjusted. As Henderson told the British science journal Nature in December 1979, GMAG had been "slightly embarrassed" when the NIH relaxed its controls in 1978, but it was now "extremely difficult to detect the practical difference between the two systems." Henderson was right, but only for a month or so, whereupon the American controls plunged downward once again. The British containment levels followed eight months later. As one scientist involved in the development of the risk assessment scheme observed: "[The scheme was] a peculiarly British way of saying 'OK, we're not changing anything, but in fact, we're changing everything.' "45 The fear of being placed at a competitive disadvantage by weaker controls elsewhere provided a powerful catalyst for the achievement of a careful parity between the two systems.

\section{Concluding Assessment}

In conclusion, critical appraisal of differing historical interpretations of the formation of genetic engineering policy in Britain and the United States is both possible and desirable. In Fredrickson's "Science and the Cultural Warp," "science" appears as a protected zone of universal knowledge, and "culture" a pernicious influence from which science must be protected. The dismantling of genetic engineering controls is depicted as the natural and logical consequence of allowing the strong lights of reason and experience to shine on the public's irrational fear of the unknown. In contrast, methods that leave open the possibility of examining social dimensions of science show that there was nothing "logical" or "natural" about the evolution of genetic engineering policy. Parity between the British and American controls resulted not from rational, asocial analysis of the biohazard problem but from the neutralization of countervailing interests and from the impetus to negate 
the issue produced by the intensifying scientific and industrial desire for rapid development of the field.

To contest "readings" of historical evidence - to debate the categories of analysis, the scope of interpretation, and the evidence to be encompassed by any intcrpretation-strikes at real problems in history. That this is no matter of indifference can be seen by the persistence and passion of the views espoused by both actors and interpreters. In contrast to a poststructuralist treatment of these events, it is assumed that comparison and evaluation can proceed, however difficult this may be. Moreover, the desirability of that struggle should be emphasized. The postmodern acceptance of epistemological relativism not only marginalizes the social study of science but, at the same time, creates an interpretative vacuum. Scientific and technological development is implicated in some of the most extreme global problems poverty, war, environmental degradation. Its critical evaluation should not be abandoned.

\section{Notes}

1. Fredrickson (1982).

2. For an insightful and wide-ranging account of the debate among American historians, see Novick (1989).

3. Golinski (1990).

4. Nelkin (1989); Douglas (1990).

5. Lukes $(1977,6-7)$.

6. Ibid., 3.

7. Lukes (1991, chap. 6).

8. For debates among political scientists, see, for example, Saunders (1979, 33-48); for debate among historians and sociologists of science, see, for example, Woolgar (1981), Barnes (1981), MacKenzie (1981).

9. For example, Dahl (1957).

10. Bachrach and Baratz $(1962,1963,1970)$; Schattschneider (1960).

11. Schattschneider $(1960,35)$.

12. Ibid., 71.

13. Bachrach and Baratz $(1962,948)$.

14. For example, Wolfinger $(1971,1063-80)$.

15. Bachrach and Baratz $(1970,49-50)$. See also the sensitive appraisal in Frey $(1971,1094)$.

16. Lukes $(1974,23-24)$.

17. Habermas $(1970,360-75)$.

18. Lukes $(1974,57)$.

19. Ibid., 22.

20. Foucault $(1980,211)$.

21. Ibid., 131.

22. Ibid., 133.

23. Ibid., 96 . 
24. Ibid., 97.

25. Callon and Law $(1982,622)$.

26. Hartsock (1990, 169-70).

27. Shapin (1988).

28. Scott $(1989,681)$.

29. Wright (forthcoming, chaps. 2 and 3 ).

30. Ibid., chaps. 4 and 5.

31. Brenner (1974).

32. Joshua Lederberg to Martin Kaplan, 23 September 1974 (Recombinant DNA History Collection, Institute Archives, MIT).

33. For the exclusion of issues concerning military use of genetic engineering from the policy arena, see Wright (1990).

34. Lewin (1974).

35. Interview with Sydney Brenner, 11 April 1980.

36. Risk assessment lagged far behind the technology. In any case, there is important evidence indicating that key risk assessment experiments were not designed to test worst-case scenarios: Wright (forthcoming, chap. 6).

37. Wright (forthcoming, chaps. 7, 8, and 10).

38. Wright (1986a; forthcoming, chaps. 6 and 7 ).

39. Wright (1986b; forthcoming, chap. 3).

40. U.S. Department of Health, Education, and Welfare (1978).

41. "Insulin Research Raises Debate" (1979).

42. This practice was essentially the legacy of the Asilomar conference, which collectively acknowledged that the hazards of genetic engineering could be large and proposed relatively strict containment requirements.

43. Wright (forthcoming, chaps. 9, 11).

44. Interview with Robert Williamson, 13 May 1980.

45. Interview with Robin Weiss, 18 June 1979.

\section{References}

Bachrach, Peter, and Morton Baratz. 1962. Two faces of power. American Political Science Review 56:947-52.

- 1963. Decisions and non-decisions. American Political Science Review 57:632-42.

1970. Power and poverty: Theory and practice. New York: Oxford University Press.

Barnes, Barry. 1981. On the "hows" and "whys" of cultural change. Social Studies of Science 11:481-97.

Brenner, Sydney. 1974. Evidence for the Ashby Working Party. Paper submitted to the Working Party on the experimental manipulation of the genetic composition of microorganisms, 26 September, Recombinant DNA History Collection, Institute Archives, MIT.

Callon, Michel, and John Law. 1982. On interests and their transformation: Enrollment and counter-enrollment. Social Studies of Science 12:615-25.

Dahl, Robert. 1957. A preface to democratic theory. Chicago: University of Chicago Press.

Douglas, Susan. 1990. Review of Bijker, Hughes, and Pinch (eds.), The Social Construction of Technological Systems. Isis 81:80-83.

Foucault, Michel. 1980. Power/knowledge: Selected interviews and other writings, 1972-1977. New York: Pantheon. 
Fredrickson, Donald. 1982. Science and the cultural warp: RDNA as a case study. Paper presented at the annual meeting of the American Association for the Advancement of Science, Washington, DC.

Frey, Frederick. 1971. Comment: On issues and non-issues in the study of power. American Political Science Review 65:1081-101.

Golinski, Jan. 1990. The theory of practice and the practice of theory: Sociological approaches to the history of science. Isis 81:492-505.

Habermas, Jurgen. 1970. Toward a theory of communicative action. Inquiry 12:360-75.

Hartsock, Nancy. 1990. Foucault on power. In Feminism/postmodernism, edited by Linda J. Nicholson, 157-75. New York: Routledge, Chapman \& Hall.

Insulin research raises debate on DNA guidelines. 1979. New York Times, 29 June, A18.

Lewin, Roger. 1974. Ethics and genetic engineering. New Scientist, 17 October, 16.

Lukes, Steven. 1974. Power: A radical view. London: Macmillan.

- 1977. Essays in social theory. New York: Columbia University Press.

1991. Moral conflict and politics. Oxford: Oxford University Press.

MacKenzie, Donald. 1981. Interests, positivism and history. Social Studies of Science 11:498-503.

Nelkin, Dorothy. 1989. Science studies in the 1990s. Science, Technology, \& Human Values 14:305-11.

Novick, Petet. 1989. That noble dream: Objectivity and the American historical profession. Cambridge: Cambridge University Press.

Saunders, Peter. 1979. Urban politics: A sociological interpretation. London: Hutchinson.

Schattschneider, E. E. 1960. The semi-sovereign people. New York: Holt, Rinehart \& Winston.

Scott, Joan Wallach. 1989. History in crisis? The others' side of the story. American Historical Review 94:680-92.

Shapin, Steven. 1988. Following scientists around: Review of Latour, Science in Action. In Social Studies of Science 18:533-50.

United States. Department of Health, Education, and Welfare. 1978. Minutes, meeting of DHEW committee with representatives of the pharmaceutical manufacturers' association, 12 October.

Wolfinger, Raymond. 1971. Nondecisions and the study of local politics. American Political Science Review 65:1063-80.

Woolgar, Steve. 1981. Interests and explanation in the social study of science. Social Studies of Science 11:365-94.

Wright, Susan. 1986a. Molecular biology or molecular politics? The production of scientific consensus on the hazards of recombinant DNA technology. Social Studies of Science 16:593-620.

- 1986b. Recombinant DNA technology and its social transformation. Osiris 2:303-60.

- 1990. Biotechnology and the military. In Agricultural bioethics: Implications of agricultural biotechnology, edited by S. Gendel, A. D. Kline, D. M. Warren, and S. Yates, 76-98. Ames: Iowa University Press.

. Forthcoming. Molecular politics: The formation of regulatory policy for genetic engineering in the United States and Britain. Chicago: University of Chicago Press.

Susan Wright is the Head of the Science and Society Program of the Residential College and also teaches in the Department of Political Science at the University of Michigan (Ann Arbor, MI 48109 USA). She is the coauthor and editor of Preventing a Biological Arms Race (1990) and author of Molecular Politics: The Formation of Regulatory Policy for Genetic Engineering in the United States and Britain (forthcoming). 